Bolm. Zool., Univ. S. Paulo $8: 165-187,1984$

\title{
SCAPHOCALANUS AND SCOLECITHRICELLA (COPEPODA, CALANOIDA, SCOLECITHRICIDAE) FROM THE EPIPELAGIAL OFF SOUTHERN BRAZIL: A TAXONOMIC AND DISTRIBUTIONAL SURVEY
}

\author{
ANTONIO FREDERICO CAMPANER
}

Departamento de Zoologia. Instituto de Biociências. Universidade de São Paulo (USP) C.P. 20.520. 01000, São Paulo-SP, Brasil. (recebido em 26.III.1984)

RESUMO - Foram estudadas, taxonomica e quantitativamente, duas espécies de Scaphocalanus, $S$. curtus e S. echinatus, e cinco de Scolecithricella, S. tenuiserrata, S. vittata, $s$. dentata, S. ovata e S. profunda, provenientes de amostras de pláncton coletadas no epipelagial nerítico e oceánico, ao iargo do SE-S do Brasil. Scolecithricella abysealis, coletada no Pacífico e Atlântico ao largo da América do Sul, foi igualmente anaiisada e, então, comparada à sua similar, $S$. profunda. Forneceu-se uma chave de classificação para as fêmeas das espécies de Scolecithricella estudadas e propós-se novos sinónimos para scaphocalanus curtus, Scolecithricella vittata e S.ovata. Os dados de ocorréncia e densidade foram somados aos da distribuição mundial, conhecida para cada espécie. Foram feitas, finalmente, algumas considerações sobre os padrōes de distribuição e a importância relativa das ca racterísticas morfológicas das espécies, no sentido de facilitar a taxonomia desses gêneros.

ABSTRACT - Two species of Scaphocalanus, S. curtus and S. echinatus, and five of scolecithricella, $s$. tenuiserrata, $S$. vittata, $S$. dentata, $S$. ovata and $S$. profunda were taxonomically and quantitatively studied from plankton samples col lected in the neritic and oceanic epipelagial off southern Brazil. Scolecithricella abyssalis from SE Pacific and SW Atlantic is also similarly analysed and then compared with S. profunda. A key is given for the Scolecithricella (fema les) species and new synonyms are proposed for scaphocalanus curtus, Scolecithricella vittata and $S$. ovata. Present data on occurrence and density are added to the known world distribution of each species. Some considerations about the dis tributional patterns and relative importance of the morpholo gical structures are made to facilitate the taxonomy of the se genera. 


\section{INTRODUCTION}

The scolecithricid copepods of the genera scaphocala nus and Scolecithricella were taxonomically reviewed by Brad ford (1973) and Park (1980, 1982), who also reported occur = rence and distribution in antarctic and subantarctic waters. Most of these aspects were summarized by Bjornberg (1981) for the SW Atlantic.

From 1975 to 1979, the R/V "Prof W. Besnard" of the University of São Paulo performed seven cruises off southern Brazil fulfilling a research project referred to as FINEP I IOUSP. The copepods collected have been qualitatively and quantitatively studied, with emphasis on some species and ge nera which are not well known.

The two genera contain, together with scolecithrix danae and $s$. bradyi, the most frequent and/or abundant scoleci thricid species found in the samples analysed until now. Besides these distributional aspects, the possibility of exami ning well-preserved material led me to a taxonomic survey, the results of which are also described and discussed.

The plankton samples studied here were collected with a BONGO net $0.333 \mathrm{~mm}$ mesh in all stations of transects I to IV (Fig. I) of cruises I (Nov./Dec., 1975) and III (May, 1976) Tows were made obliquely from $5 \mathrm{~m}$ above the bottom to the surface and from $200 \mathrm{~m}$ to the surface in neritic and oceanic waters, respectively Density is expressed as numbers of individuals in the volume of water filtered $\left(\mathrm{m}^{3}\right)$; this vo lume is calculated from flowmeter data. The epipelagial is referred to as the upper $200 \mathrm{~m}$, and the mesopelagial as the zone from 200 to $1000 \mathrm{~m}$ depth.

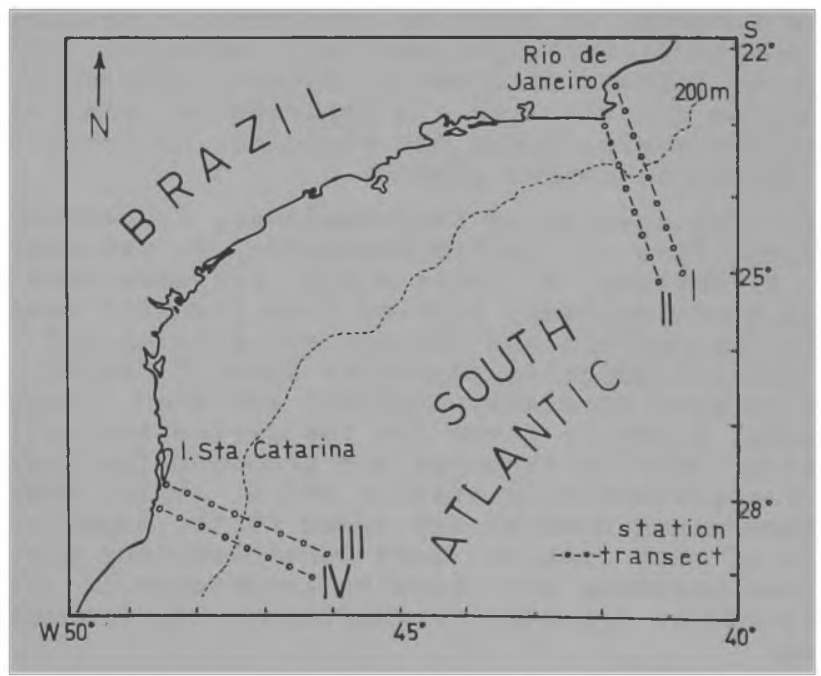

Fig. 1 - Transect and station positions in the sampling area. 
Von Vaupel Klein's (1982) morphological terminology and appendage abbreviations were almost totally adopted here. The only two changes are indicated in the following list : C - cephalosome (instead of cephalon), Pr - prosome (instead of cephalothorax), Ur - urosome, Thl to Th5 - thoracic somites 1 to 5, Gn som - genital somite, Al - antennula, A2 - an tenna, Md - mandible, Mxl - maxillula, Max - maxilla, Mxp = maxilliped, $\mathrm{Pl}$ to $\mathrm{P} 5$ - legs 1 to $5, \mathrm{Bal}$ to $\mathrm{Ba} 2$ - basipodal segments 1 to $2, \operatorname{Re} 1$ to $\operatorname{Re} 3$ - exopodal segments 1 to 3 , Ril to Ri 3 - endopodal segments 1 to 3 . The British Museum (Natu ral History) is referred to as BMNH.

\section{TAXONOMY AND DISTRIBUTION}

Scaphocalanus Sars, 1900

Scaphocalanus curtus (Farran, 1926)

Fig. $2 a-d$

Scolecithrix curta Farran, 1926: 259-60, pl. 7, figs 1-6.

Scaphocalanus curtus.- Farran, 1929: 250.-Tanaka, 1961: 1835, fig. 124 ( + only).- Bjbrnberg, 1963: 41-2, fig. 22. Vervoort, 1965:64-5.- Hure and Scotto di Carlo, 1968:15357 , figs 1-2.- Bjurnberg, 1973:331-3.

Scaphocalanus temporalis of Tanaka, 1953:132.

Scaphocalanus glacialis of Tanaka, 1953:132.

Scaphocalanus Zongifurca Giesbrecht $\sigma .-$ Tanaka, 1961:178,fig. 121.

Scaphocalanus similis Hure and Scotto di Carlo, 1968:157-61, figs 3-4.- Park, 1982:122-3, fig. 29. (new synonymy) Scaphocalanus subcurtus Park, 1970:499, figs 113-9

Material examined.- Type material: \% holotype $1.30 \mathrm{~mm}$ long, BMNH slide n: 1926.12.6.45, examined by Dr. G. A. Boxshali (Curator, BMNH); paratypes ( 3 damaged ++ ), BMNH reg f $_{\text {n. } 1926}$ 12.6.28, not examined.- FINEP/IOUSP collection: 10 +f, oblique tows from 200-41 m to surface in oceanic waters and South Atlantic central water over the shelf off the States of Rio de Janeiro (Trans. II, May 76) and Santa Catarina (Trans.III - Nov./Dec. 75 and IV - Nov./Dec. 75 and May 76), SW Atlan tic, Brazil.

Type locality.- Bay of Biscay, $W$ coast of Ireland, Lat. $47^{\circ}$ $29^{\prime}$ to $46^{\circ} 4^{\prime} \mathrm{N}$, Long. $8^{\circ} 18^{\prime}$ to $7^{\circ} 15^{\prime} \mathrm{W}$.

Remarks ( $\%$ ).- Length: total, $0.93-1.05 \mathrm{~mm}$ (10 specimens); $\operatorname{Pr} 0.76-0.96 \mathrm{~mm}$ (average 0.82 ) and Ur 0.15-0.19 mm (average $0.18)$. Proportional lengths of Ur-somites plus furca 17.8: 12.6:11.8:7.2:10.6 = 60.0. Pl Re2 (Fig. 2a) with an external terminal lobe bearing a very hyaline spine, sometimes absent (Fig. 2al); Pl Ri with 3 inner marginal and 2 terminal se tae. $\mathrm{P} 4 \mathrm{Bal}$ ( $\mathrm{Fig} .2 \mathrm{~d}$ ) with ca. 5 long inner marginal seti form spines, of which at least 3 directed outward. Large ter minal spine of $\mathrm{P} 2-4$ (Figs $2 \mathrm{~b}-\mathrm{d}$ ) with serrate outer margin composed of sharp denticles with lateral flanges. P5 absent. 


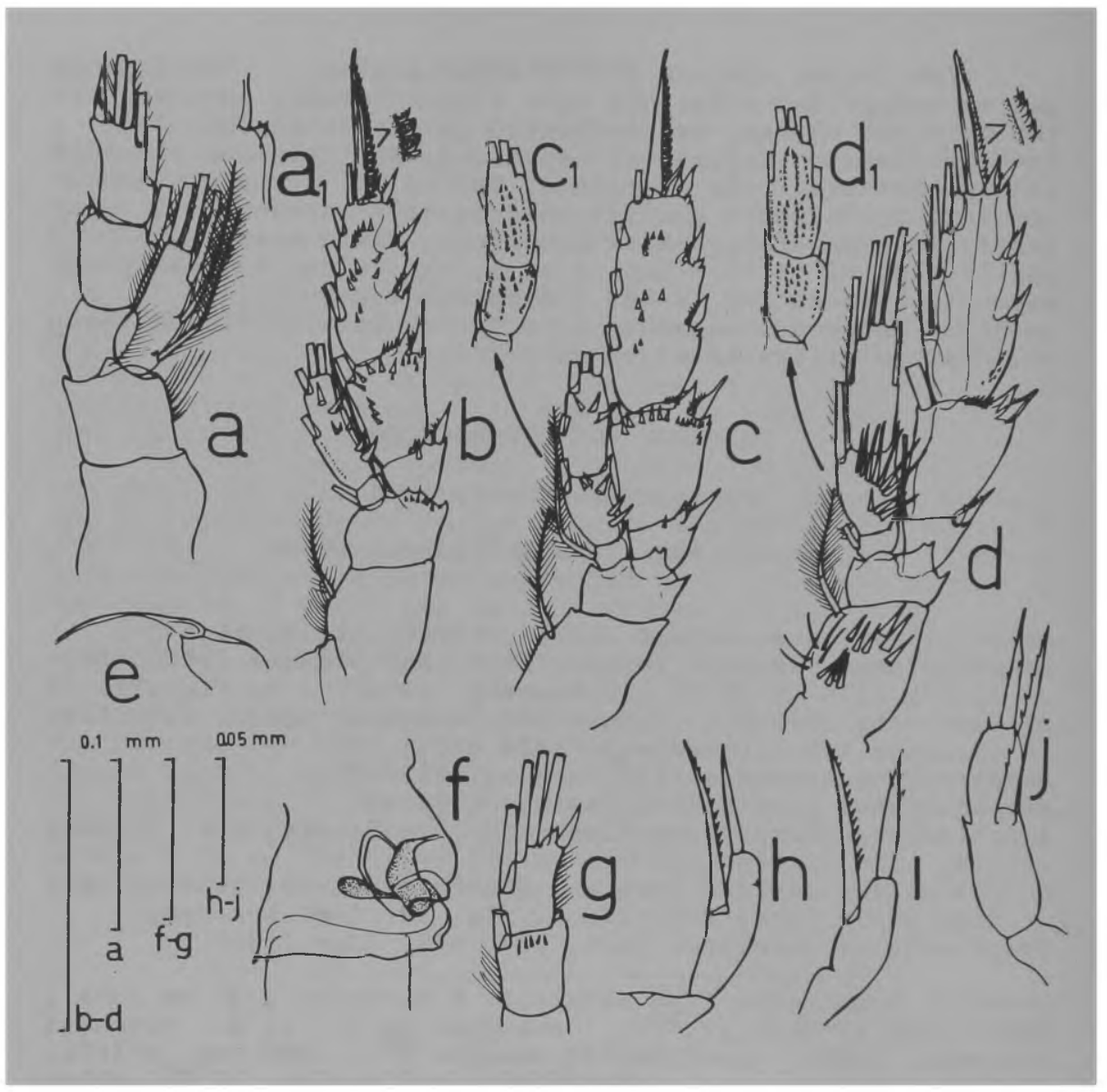

Fig. 2 - Scaphocalanus curtus, + . a, Pl, anterior; al, Spine less outer terminal lobe on $\mathrm{P} 1 \mathrm{Ba} 2$, another specimen; $\mathrm{b}, \mathrm{P} 2$, posterior; c, P3, posterior; cl, P3 Ri, anterior; d, P4, pos terior; di, P4 Ri, anterior. Scaphocalanus echinatus, f. e, Rostrum, lateral; $f, G n$ som, lateral; $g, P l \operatorname{Re} 2-3$, posterior; $\mathrm{h}$, P5 of $1.75 \mathrm{~mm}$ specimen; $i, P 5$ of $1.85 \mathrm{~mm}$ specimen; $j$, P5 of $2.19 \mathrm{~mm}$ specimen.

In the original description of the female (Farran, 1926), the total length ranged from 1.06 (a paratype) to $1.30 \mathrm{~mm}$ (the holotype); the $\mathrm{Pr}$ and $\mathrm{Ur}$ of a paratype were 0.86 and $0.28 \mathrm{~mm}$ long, the proportional length of Ur-somites plus furca 18:12:12:7:11 = 60, and the number of outer and terminal setae of $P 1$ Ri were 4 in a paratype and 5 in the holotype.

Dr. G. A. Boxshall kindly sent me his drawings of the dissected $\mathrm{PI}, \mathrm{P} 4$ and Ur from the holotype slide. In these, 


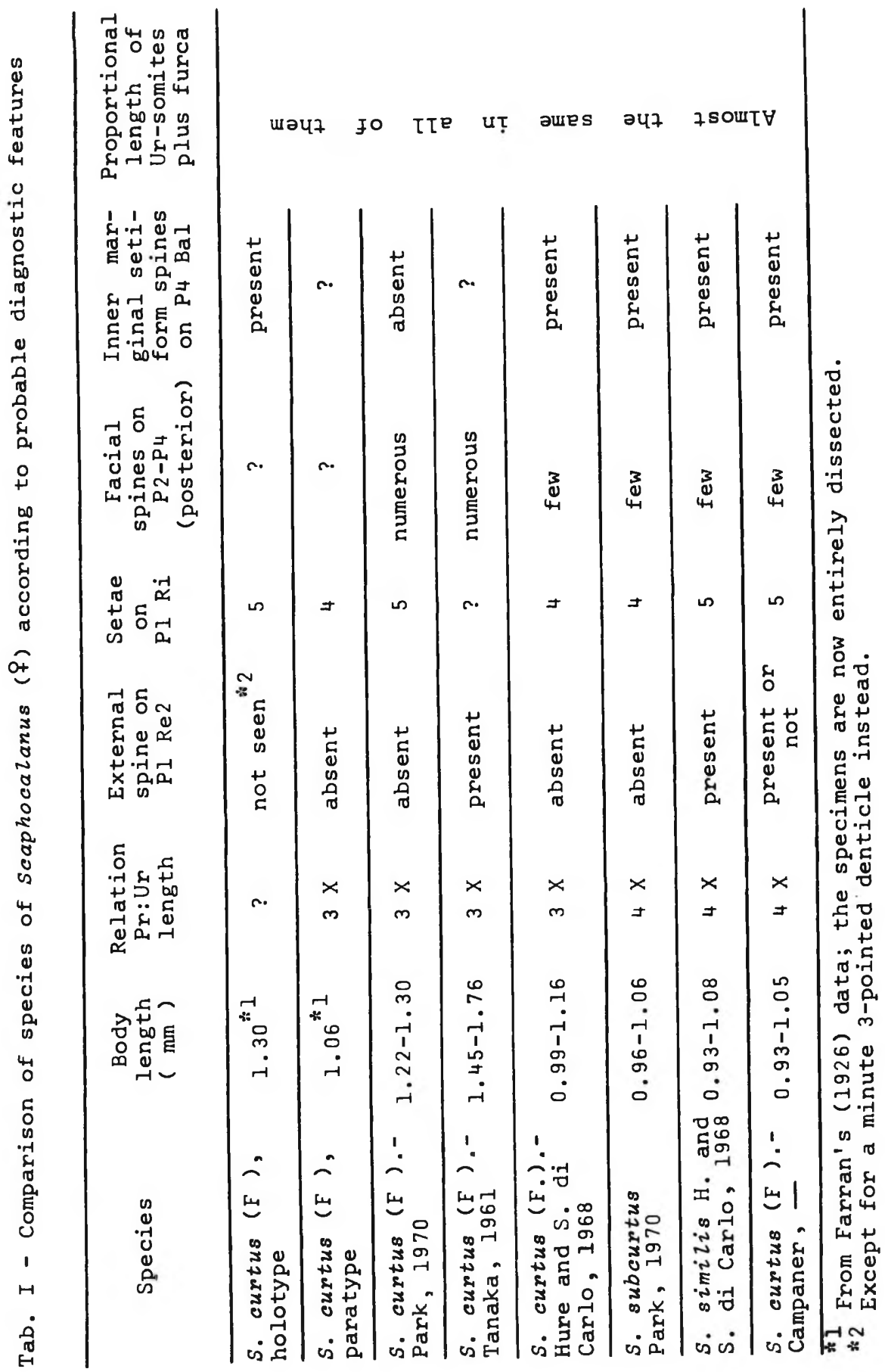


the $\mathrm{Pl}$ has 5 setae on $\mathrm{Ri}$ and an external terminal lobe on Re2, but no spine could be seen on it except for a minute 3pointed denticle (Boxshall, personal communication), which might be the same ornament which I observed in the spineless lobe of one specimen (Fig. 2al); the $\mathrm{P}_{4} \mathrm{Bal}$ has the long inner marginal setiform spines shown in Fig. $2 \mathrm{~d}$ and the propor tional lengths of Ur-somites plus furca is 17.2:12.5:12.6:8.2 $: 9.5=60.0$ These are very similar to the proportions of S. similis (recalculated from Hure and Scotto di Carlo's data, 1968:157) and of S. subcurtus (deduced from Park's drawings, 1970: figs 113 and 115)

Comparing the descriptions of these species, available in the literature, with the BMNH type material (Tab. I), it is impossible to define the specific characters of each species. Until new information is added, $S$. subcurtus and $S$. si $m i l i s$ seem to be synonyms of $S$. curtus. Bradford (1973) had already considered $S$. subcurtus as a synonym, but without $\underline{\underline{e}}$ marks.

Habitat and distribution.- Mesopelagial and epipelagial in the NE and SE Atlantic, and Pacific off New Zealand and Ja pan (Vervoort, 1965). Additional records: SW Atlantic off Brazil (Bjornberg, 1963, 1965, 1981), Bay of Naples and South Adriatic (Hure and Scotto di Carlo, 1968), Caribbean Sea and Gulf of Mexico (Park, 1970) and SW coast of Australia (Park, 1982) It occurred off southern Brazil (present study) with density varying from 0.01 to $0.74 \mathrm{~m}^{-3}$ and from 0.01 to 0.20 $\mathrm{m}^{-3}$ in neritic and oceanic waters, respectively.

\section{Scaphocalanus echinatus (Farran, 1905) Fig. $2 e-j$}

Scolecithrix echinata Farran, 1905:37-8, pl. 4, figs 15-8, pl. 5, figs 12-7

Scaphocalanus echinatus.- Farran, 1926:258. - Farran, 1929: 250, fig. 17.- Rose, 1933:149, fig. 153.-Wilson, 1950 : 326-7, pl. 34, figs 510-1.- Tanaka, 1961:181-3, fig.123.Grice, 1962:213, p1. 19, figs. 6-7.- Bjornberg, 1973:3313.- Bjornberg, 1981:637-8, fig. 213.- Park, 1982: 101-4, figs $15-6$.

Material examined.- FINEP/IOUSP collection: 20 \$9, oblique tows from $200 \mathrm{~m}$ to surface in oceanic waters off the States of Rio de Janeiro (Trans. II, May 76) and Santa (Trans. III - Nov./Dec. 75 and IV - May 76), SW Atlantic, Brazil.

Type locality - Porcupine Bank, W coast of County Galway, Ire land, Lat. $52^{\delta} 24^{\prime} \mathrm{N}$, Long. $13^{\circ} 34^{\prime} \mathrm{W}$.

Remarks ( $($ ).- Total length (20 specimens) 1.58 to $2.19 \mathrm{~mm}$, average $1.76 \mathrm{~mm}$. Rostrum (Fig. 2e) and $\mathrm{Gn}$ som (Fig. 2f) as described by Park (1982: figs 15a,c) P1 Re2 (Fig. 2g) with tiny spine. P5 varies (Figs $2 h-j$ ), armed with inner spine with serrate lateral margins or row of spinules; terminal 
spine spinulated or not; and 2 more smaller spines, which may be absent.

Habitat and distribution.- Tropical and temperate regions of the world oceans (Park, 1982:103-4) Additional references to SW Atlantic off Brazil in Bjornberg (1965:225;1981:637)

It occurred with 0.01 to $0.24 \mathrm{~m}^{-3}$ density in oceanic waters off southern Brazil (present study)

\section{Scolecithricella Sars, 1902}

Key to females of Scolecithricella species in the SW Atlantic off Brazil

1. Posterior-lateral corner of last prosomal somite indented

- Posterior-iateral corner of last prosomal somite smoothly curved (Fig. 3b) . . . . . 3

2 Pl Rel with one outer terminal spine; inner margin of $\mathrm{P} 4$ Bal nude; $P 5$ with basal segment, distal two-thirds of ter minal segment semi-ovally outlined. . . S. ovata

- Pl Rel without outer terminal spine; inner margin of P4 Bal with short stout setules; P5 arising directly from intercoxal plate . . .. . . . . S S. dentata

3. Body length less than $\dot{1} .20 \mathrm{~mm}$; $\dot{M} \dot{1} \dot{\mathrm{Ba}} \dot{2}$ with 3 setae; P5 outer margin spineless...... . S. tenuiserrata

- Body length above $1.35 \mathrm{~mm}$; Mxl Ba2 with 5 setae; P5 outer margin with tiny spine. $\quad \ldots . . \quad \ldots \quad . \cdot \dot{j}^{4}$

4. One of the two terminal spines of $\ddot{P} \dot{5}$ more than $\dot{i} \dot{5} \dot{x}$ length of inner marginal spine ... ... .. . S. vittata

- The two terminal spines of $\dot{P} 5$ smalier than inner marginal

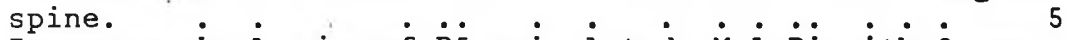

5. Inner marginal spine of $\dot{\mathrm{P}} \dot{5}$ spinulated; $\dot{M} x \dot{\mathrm{R}} \dot{\mathrm{R}}$ with $\dot{8}$ se -

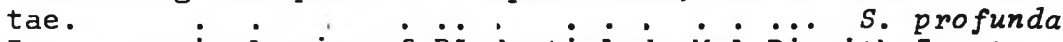

- Inner marginal spine of $\dot{P} \dot{5}$ denticled; $\dot{M} x \dot{R} \dot{R}$ with 7 setae. S. abyssalis

Scolecithricella tenuiserrata (Giesbrecht, 1892)

Figs $3-5$

Scolecithrix tenuiserrata Giesbrecht, 1892:266-84, Pl. 13

figs I3, 16, 24-5, 39, pl. 37, figs 4, i2. - Giesbrecht and Schmeil, $1898: 43$.

Scolecithricella tenuiserrata. - Grice, 1962:208, 211,pl. 17, figs 9-21 (f only).- Tanaka, 1962: 48-50, fig. 133.-Bjurn berg, 1963:122-3.- Vervoort, 1965:83-4.- Owre and Foyo, $1967: 24,60$, figs $107,382-3$ - Bjbrnberg, 1973:333.

?Scolecithriceila tenuiserrata ó. - Grice, 1962:208, 211 , pl.

18, fig. l.

Material examined.- FINEP/IOUSP collection: 40 $\$$, oblique tows from 200-23 $\mathrm{m}$ to surface in oceanic waters and South Atlantic central water over the shelf off the States of Rio 


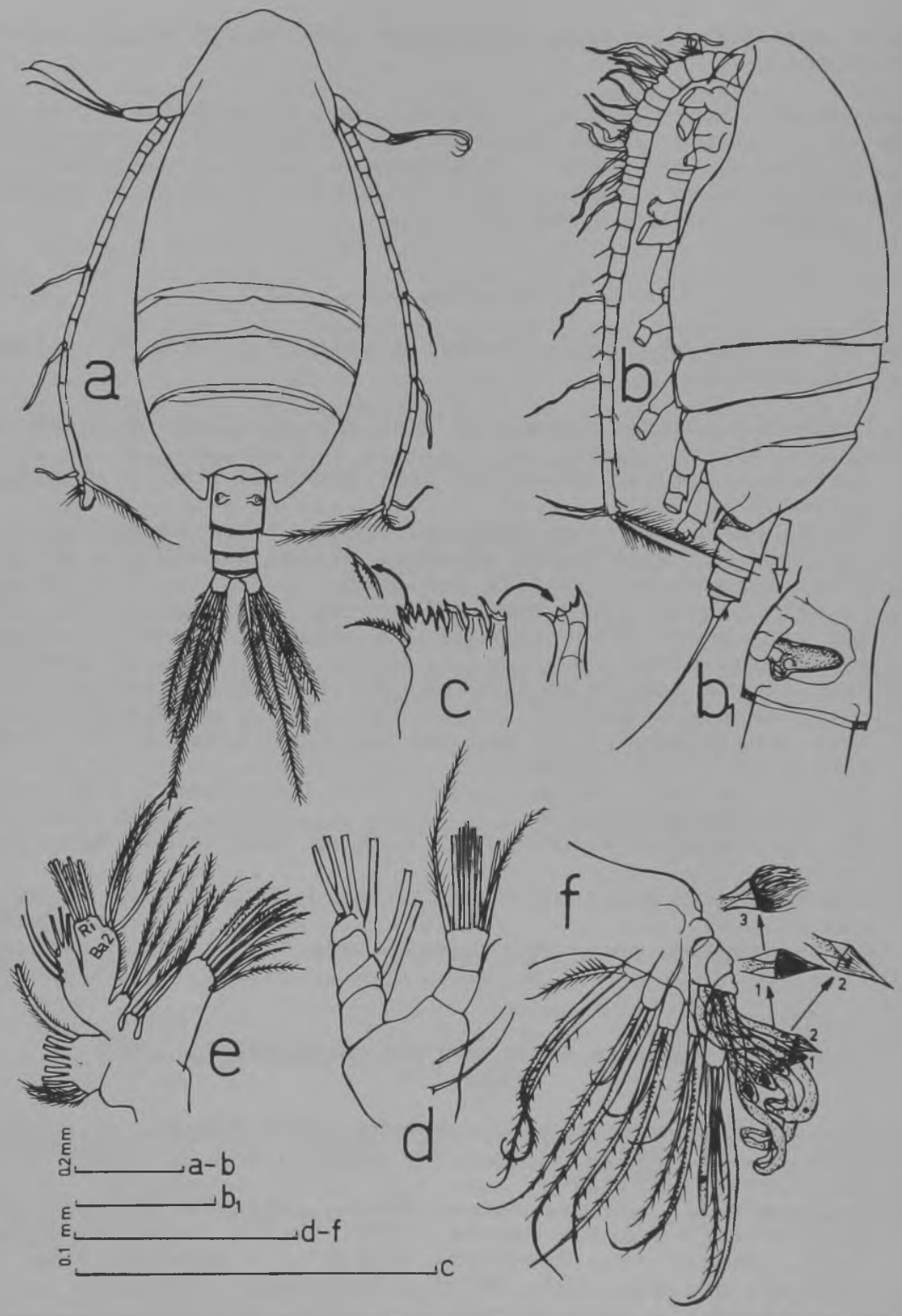

Fig. 3 - Scolecithricella tenuiserrata, $\$$. a, Habitus, dor sal; b, Habitus, lateral; bl, Gn som enlarged; c, Gnathoba sis of Md; d, Palp of Md; e, Mxl; f, Max:1-2, types of brush -like sensory setae; 3 , variety of type 1 . 
de Janeiro (Trans. I and II, Nov./Dec. 75 and May 76) and Santa Catarina (Trans. III and IV, Nov./Dec. 75 and May 76), SW Atlantic, Brazil.- 166ర, oblique tows from $122 \mathrm{~m}$ to surfa ce in South Atlantic central water over the shelf off the States of Rio de Janeiro (Trans. I - May 76 and II - Nov. I Dec. 75) and Santa Catarina (Trans. III and IV - May 76), SW Atlantic, Brazil.

Type locality.- Mediterranean Sea, Gulf of Naples, Lat. $41^{\circ} \mathrm{N}$.

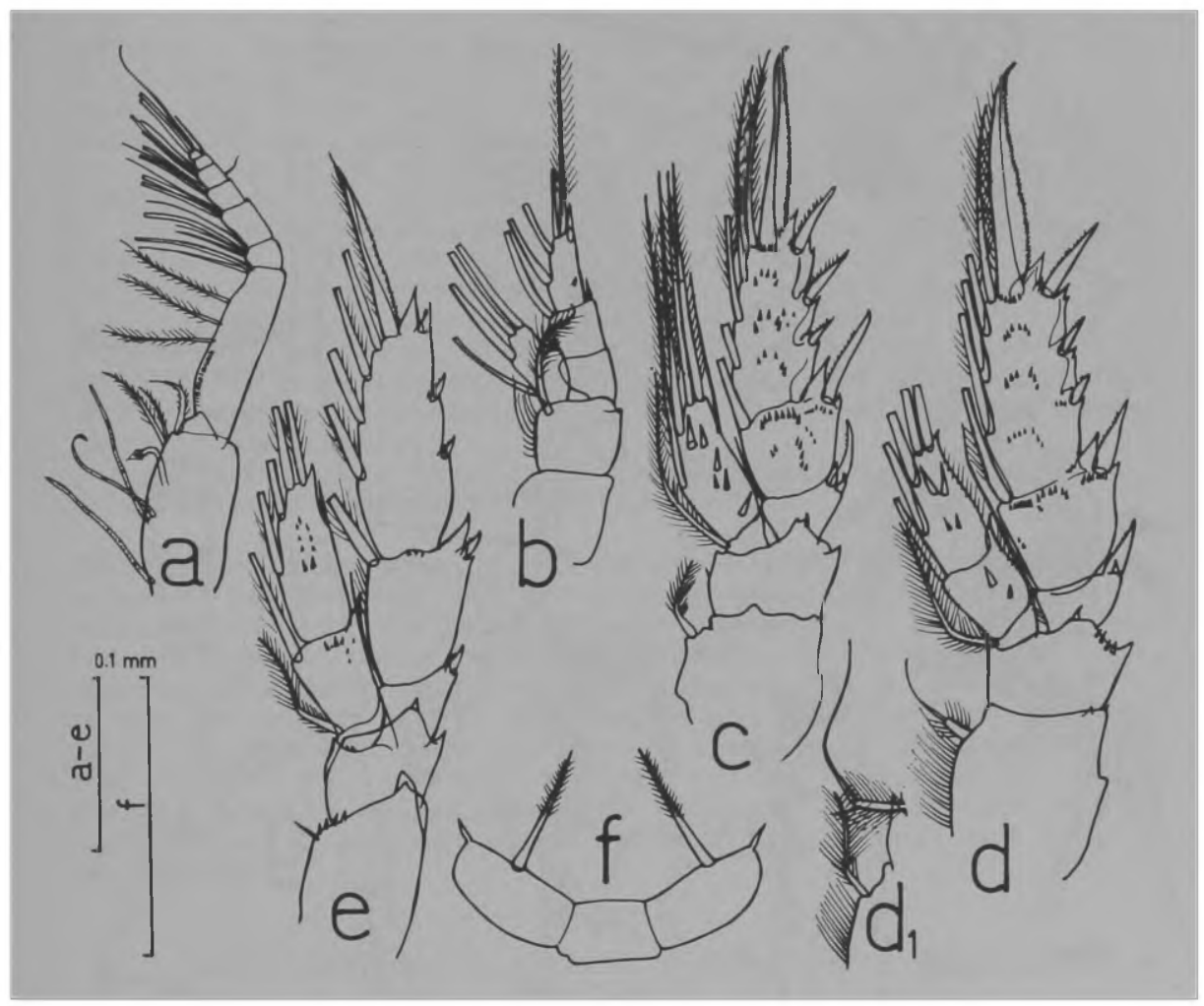

Fig. 4 - Scolecithricella tenuiserrata, $f$ a, Mxp; b, Pl, posterior; c, P2, posterior; d, P3, posterior; dl, varieties of inner seta on $\mathrm{P} 3 \mathrm{Bal}$ and Ril; $e, \mathrm{P}_{4}$; $f$, $\mathrm{P} 5$, pair.

Description.- 9 : Total length (40 specimens) 1.00-1.15 mm, average $1.07 \mathrm{~mm}$. Pr ovally outlined (Fig. 3a) with postero-lateral corners slightly pointed (Fig. $3 b$ ). Seminal recep tacles (Fig. 3bl) straight and directed dorsally. Structure of Md palp (Fig. 3d), Max (Fig. 3f) and Mxp (Fig. 4a) common to the genus. Masticatory edge of Md gnathobasis (Fig. 3c) with a stout setulose dorsal seta, 5 small bicusped teeth 
with one cusp strongly denticulated toward tip (see also Fig. $8 \mathrm{~b})$, and 3 large multicusped teeth. Ba2 and Ri of Mxl coales ced (Fig. $3 e$ ) with 3 and 5 setae, respectively. Brush-like sensory setae of Max with types 1 and 2 and the variety 3 of type 1 in Fig. $3 \mathrm{f}$ Structure and armature of Pl-5 as in Figs $4 \mathrm{~b}-\mathrm{f}$.

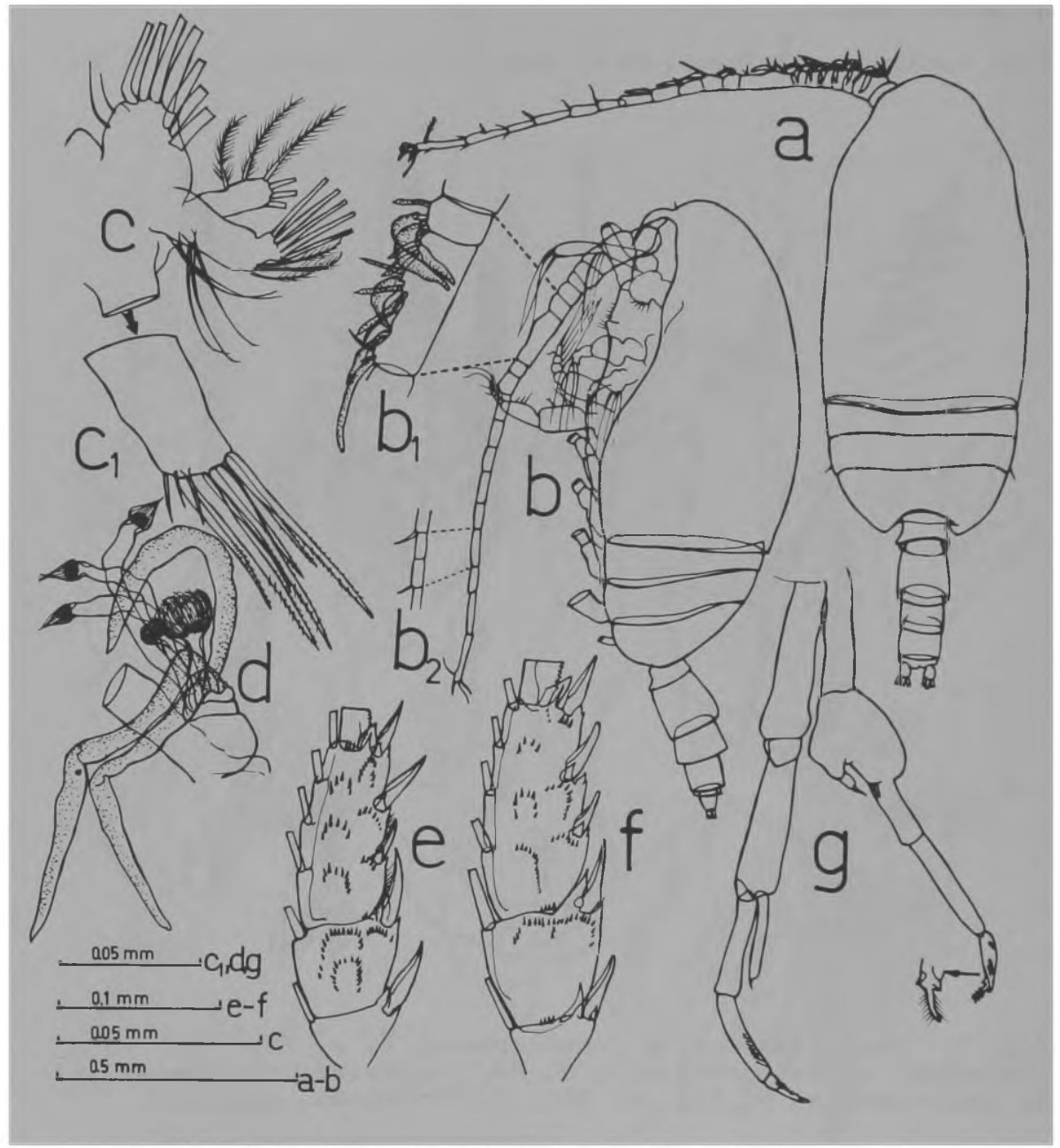

Fig. 5 - Scolecithricella tenuiserrata, 6 . a, Habitus, dor sal; b, Habitus, lateral; bl, Al armature of segments 7-8; b2, Segment 16 of right Al of another specimen; c, Mxl, inner lobe 1 removed; cl, Inner lobe 1 of Mxl; d, Max Ri; e, P2 Re, posterior; f, P3 Re, posterior; g, P5, pair. 
6 : Total length (16 specimens) $1.19-1.33 \mathrm{~mm}$, average $1.26 \mathrm{~mm}$. Pr (Fig. 5a) laterally compressed relative to female. Al 19-segmented, segment 16 of right Al divided into 2 separate segments on one specimen (Fig. 5b2) 0ther prosomal appendages structurally similar to female's, except for (I) smaller length of 3 innermost setae on Mxl inner lobe 1 (Fig. 5cl) and 2 brush-like sensory setae on Max Ri (Fig. 5d), (2) greater number and different arrangement of spines on Re surfaces of $P 2$ and P3 (Figs 5e-f), and(3) struc ture and development of P5 (Fig. $5 \mathrm{~g}$ )

Remarks.- The species description agrees in general with tho se of Owre and Foyo (1967) for both sexes, Grice (1962) for female and Tanaka (1962) for male. The male right P5 $\operatorname{Re} 3$ was drawn differently by Grice, it is uncertain if he simplified the drawing or if his specimens are Scolecithrix dubia Giesbrecht, 1892 (pl. 13, fig. 29), considered by Park (1980:42) as the male of Scolecithricella dentata (for comparison see also Tanaka, 1937:260-1, fig. 11, and Owre and Foyo,1967:23, fig. 94) As the majority of the $P 5$ of my specimens are partially damaged, I cannot decide upon the possibility of a structural variation. The male described by Rose (1942) as Amallothrix tenuiserrata is according to the characteristics of P5 (compare with Park, 1980:40, fig. 6h-i) that of Scolecithricella vittata.

According to Bradford's (1973) generic definition, this is definitely a Scolecithricella species.

Habitat and distribution.- Scolecithricella tenuiserrata seems to be the most characteristic epipelagic scolecithri cella species in the tropical and subtropical $\mathrm{N}$ and $\mathrm{S}$ Atlantic. Vervoort (1965) furnished distributional data for the Indo-Pacific and Mediterranean, Owre and Foyo (1967) and Gri ce and Hulsemann (1965) for the NW and NE Atlantic, respecti vely. It occurred (present study) frequently and ranged from 0.02 to $3.71 \mathrm{~m}^{-3}$ and from 0.02 to $1.77 \mathrm{~m}^{-3}$ density in neritic and oceanic epipelagial off southern Brazil, where the South Atlantic central water spreads under shelf and tropi cal waters.

Scolecithricella vittata (Giesbrecht, 1892) Fig. $6 a-e$

Scolecithrix vittata Giesbrecht, 1892:266-86, pl. 13, figs $2,23,32,34,35, \mathrm{pl} .37$, figs $5,8 .-$ Giesbrecht and Schmeil, 1898:43, fig. 6.- Sars, 1924: pl. 52, figs 15-20. scolecithricella vittata. - Sars, 1925:190-1. - Farran, 1926: 259. - Farran, 1929: 247.- Rose, 1933:158, fig. 173.- Ro se, 1942:140-2, figs 31-4.-Wilson, 1950:335, pl. 18,figs 233-4.-Grice, 1962:208, pl. 17, figs 1-8.- Tanaka, 1962: 41-2, fig. 129.- Grice and Hulsemann, 1965:221, 224.-Owre and Foyo, 1967: 61, figs 385-8.- Park, 1980:37, 39-42, figs 5-6.- Bjornberg, 1981:638-9, fig. 213 .

scolecithricella sub-vittata Rose, 1942:142-4, figs 35-7 (new synonymy) 
Amallothrix tenuiserrata $\sigma_{\text {. }}$ - Rose, 1942:163-6, figs 56-8. non scolecithricella vittata $\sigma$ - Rose, 1942:159-62, figs 535.

Material examined.- FINEP/IOUSP collection: $20 \% \$$, oblique tows from $200 \mathrm{~m}$ to surface in oceanic waters off Rio de Ja neiro State (Trans I - Nov./Dec. 75), SW Atlantic, Brazil.

Type locality.- Mediterranean Sea, Gulf of Naples, Lat. $41^{\circ} \mathrm{N}$.

Remarks. - Total length (20 specimens) 1.40-1.65 mm, average $1.55 \mathrm{~mm}$. Body (Fig. $6 \mathrm{a}$ ) and prosomal appendages similarly shaped and structured to those already described (see synony my). Few differences are observed in number and arrangement of spines on posterior surface of P2-3 Re (Figs 6c-d)

Scolecithricella sub-vittata is a variation instead of a separate species, as Rose (1942:144) had suggested in the original description; therefore it is included here in the synonymy .

Habitat and distribution.- Tropical and subtropical regions of the Atlantic, Pacific, Indian and Mediterranean (Park, 1980:40-2) Off southern Brazil (present study) it occurred with 0.11 to $0.23 \mathrm{~m}^{-3}$ density in the oceanic epipelagial off Rio de Janeiro State during Nov./Dec, and very seldom with 0.01 to $0.04 \mathrm{~m}^{-3}$ density off the States of Rio de Janeiro and Santa Catarina in May.

\section{Scolecithricella dentata (Giesbrecht, 1892) Fig. $6 \mathrm{f}-\mathrm{k}$}

Scolecithrix dentata Giesbrecht, 1892:266-86, pl. 13, figs $12,20,33, \mathrm{pl}$. 37, figs 13-4.- Giesbrecht and Schmeil, 1898:44.- Sars, 1924: pl. 52, figs 21-3.

scolecithricella dentata. - Farran, 1908:69.- Sars, 1925 : 191-2. - Farran, 1926:259. - Farran, 1929:247.- Rose, 1933: 158, fig. 174.- Rose, 1942:144-7, figs 38-41 ( $\%$, $154-6$, figs 46-8 (O).- Wilson, $1950: 333-4$, pl. 18,fig. 231 ( $f$ ).Tanaka, 1962:42-4, fig. 130.- Grice and Hulsemann, 1965 : 221,224.- Owre and Foyo, 1967:23, 60-1, figs $34,379-81$.Park, 1968:555, pl: 8, figs 13-6.- Bjornberg, 1973:332. Park, 1980:42-3, fig. 7.- Bjornberg, 1981:638-9, fig.213. non scolecithrix dentata 6 . - Wilson, 1950:333-4, pl. 18,figs 230,232 .

Scolecithrix dubia Giesbrecht, 1892:266-86, pl. 13, fig. 29. - Tanaka, 1937:260-1, fig. 11.

Material examined.- FINEP/IOUSP collection: 45 $\$ \%$, oblique tows from 200-90 $\mathrm{m}$ to surface in oceanic waters and South Atlantic central water over the shelf, off the States of Rio de Janeiro (Trans. I and II - Nov./Dec. 75 and May 76) and Santa Catarina (Trans. III and IV - Nov./Dec. 75 and May 76), SW Atlantic, Brazil. 


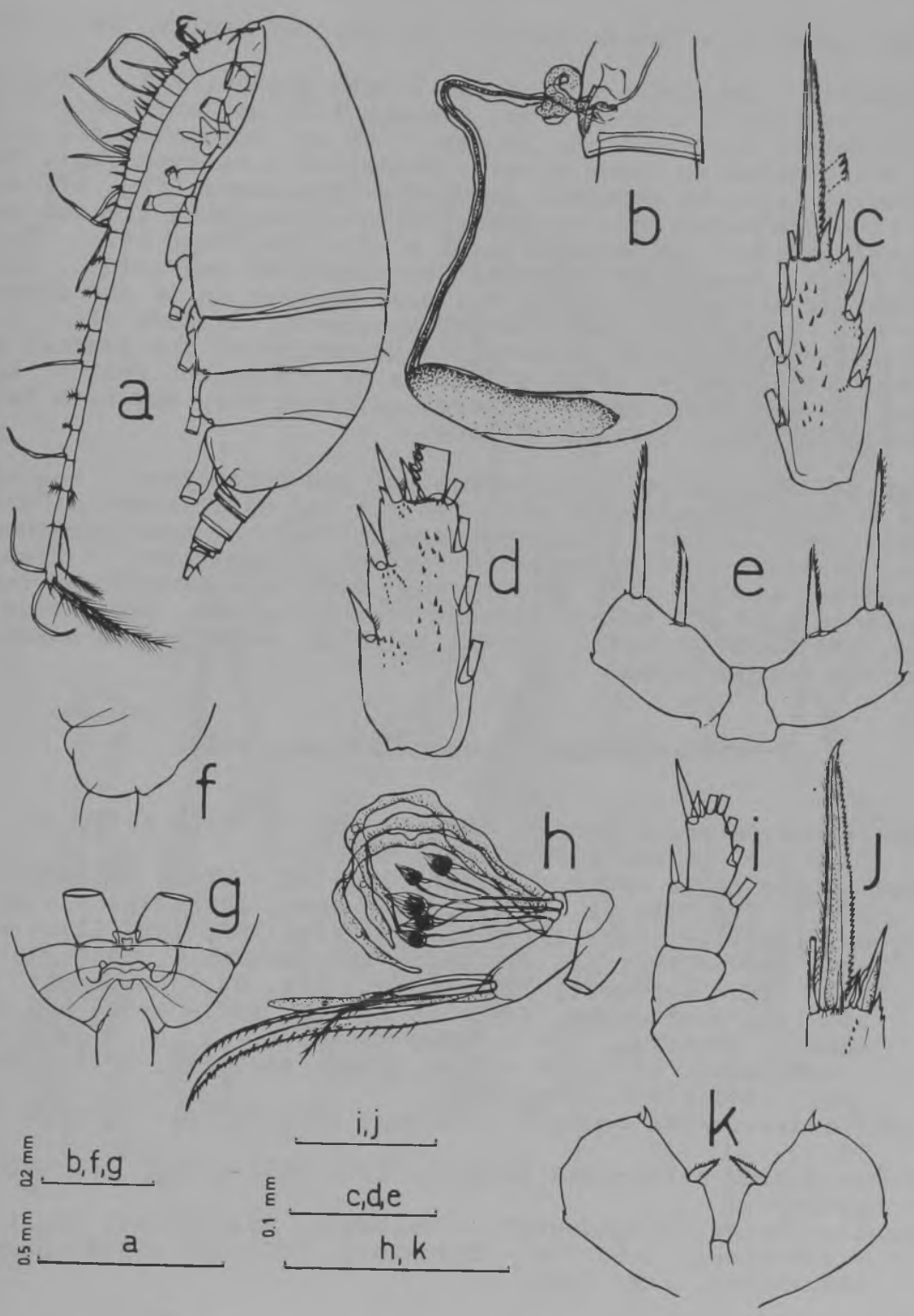

Fig. 6 - Scolecithricella vittata, + . a, Habitus, lateral; b, Gn som with attached spermatophore; c, P2 Re3, posterior; d, P3 Re3, posterior; e, P5, pair. Scolecithriceila dentata, +. $f, \operatorname{Pr}$ distal, lateral; $g$, Ditto, ventral; $h$, Max $R i$ and inner lobe 5; $i$, PI; j, P2 Re3, distal; $k$, P5, pair. 
Type locality.- Mediterranean Sea, Gulf of Naples, Lat. $41^{\circ} \mathrm{N}$.

Remarks - Specimens are of two length groups, viz. "small" (40 specimens) 1.21-1.40 mm, average $1.35 \mathrm{~mm}$, and "large" ( 5 specimens) $1.62-1.68 \mathrm{~mm}$, average $1.65 \mathrm{~mm}$. Morphological features similar to those already described (see synonymy), including indented prosomal dorso-distal corners (Fig. $6 f$ ) and bi-incised outer pointed emarginations preceding the sub-ter minal and terminal outer spines of $\mathrm{P} 2-3 \mathrm{Re}$ (Fig. 6j) From 80 "small" specimens examined (the above 40 measured plus other 40 sorted), P5 (Fig. 6k) were present in 36 and absent in 44; P5 absent in all "large" specimens. In some of the specimens lacking P5, careful examination of the sternal si te of P5 formation ( $F i g .6 \mathrm{~g}$ ) gives no indication that any leg had ever been present there, although they may have fallen off without leaving a trace.

Habitat and distribution.- Tropical and subtropical regions of $\mathrm{N}$ and $\mathrm{S}$ Atlantic, $\mathrm{N}$ and $\mathrm{S}$ Pacific and Mediterranean(Park, 1980:42-3) After $S$. tenuiserrata, it was the most frequent and abundant Scolecithricella species off southern Brazil (present study), with density from 0.03 to $0.27 \mathrm{~m}^{-3}$ and from 0.01 to $0.47 \mathrm{~m}^{-3}$ in neritic and oceanic waters, respective ly. The South Atlantic central water is probabiy its habitat in the studied area.

\section{Scolecithricella ovata(Farran, 1905)}

Fig. 7

Scolecithrix ovata Farran, 1905:37, pl. 6, figs 13-8, pl. 7, figs 1-5.- Sars, $1924: \mathrm{pl}$. 52, figs $1-6$.

scolecithricella ovata. - Farran, 1908:69.- With, 1915:208-11, pl. 7, fig. 14, pl. 8, fig. 12.- Sars, 1925: 188-9.- Ro-se, 1933:157, fig. 17i.- Wilson, 1942:208, fig. 125.-Wil son, 1950:334-5, pl. 35, fig. 527.- Brodskii, 1950:270-1, fig. 179.- Vervoort, 1951:99-101, fig. 53.- Vervoort, 1957: 102-3.- Tanaka, 1962: 55-8, fig. 137.- Grice and Hul semann, 1965:221, 224.- Park, 1968:555, pl. 8, figs 17-2i. - Bjbrnberg, $1973: 332$.- Park, 1980: 58-9,fig. 17.-Bjbrnberg, 1981:638-9, fig. 213 .

?Scolecithricella ovata ó. - Minoda, 1971:31, pl. 2, figs 1 10.

Scolecithrix subdentata Esterly, 1905:167-8, fig. 29 (new

synonymy)
scolecithricelza subdentata. - Brodskii, 1950:271-2, fig.182 - Bjornberg, 1965:224.- Bjornberg, 1973:332.- Bjbrnberg, 1981: $638-9$, fig. 213 .

Material examined.- FINEP/IOUSP collection: 3 \$f, oblique tows from $200 \mathrm{~m}$ to surface in oceanic waters off Rio de Ja neiro State (Trans. II - Nov./Dec. 75 and May 76) at night, SW Atlantic, Brazil.

Type locality.- $W$ of Achill Head, County Mayo, Ireland, Lat. $53^{2} 58^{\prime} \mathrm{N}$, Long. $122^{2} 8^{\prime} \mathrm{W}$. 


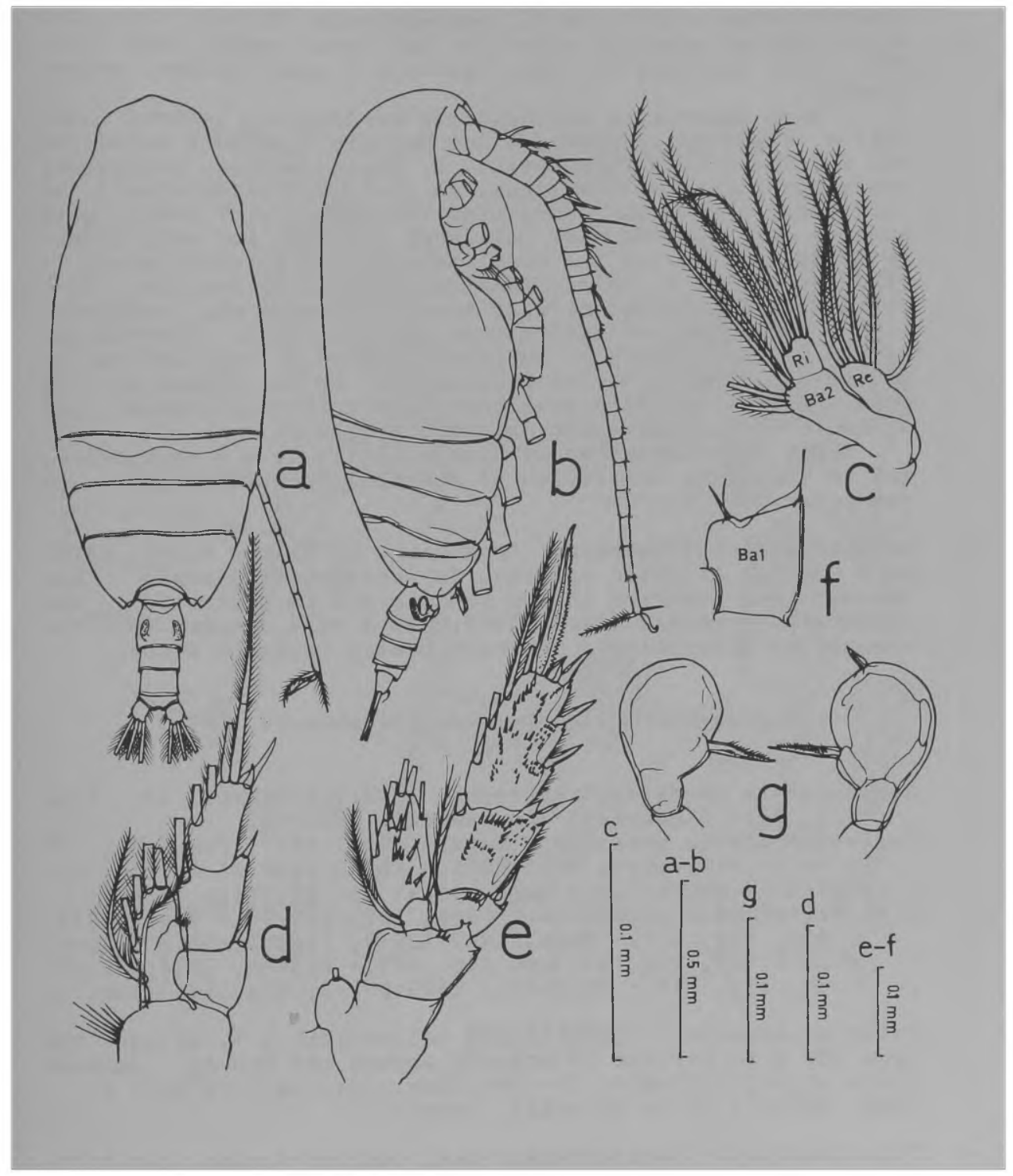

Fig. 7 - Scolecithricella ovata, 9 . a, Habitus, dorsal; b, Ha bitus, lateral; c, Mxl $\mathrm{Ba} 2, \mathrm{Ri}$ and $\mathrm{Re}$; d, Pl, posterior; $e$, $\mathrm{P} 2$, posterior; f, P4 Bal; g, P5, pair. 
Remarks.- Total lengths $1.73,1.76$ and $1.80 \mathrm{~mm}$. Prosomal pos tero-lateral conners indented (Fig. 7a-b). Mxl (Fig. 7c)with 4 and 5 setae on $B a 2$ and $R i$, respectively $P 1$ Rel (Fig. 7d) with an outer terminal spine. $\mathrm{P} 4 \mathrm{Bal}$ inner margin nude (Fig. 7f) Right and left P5 (Fig. 7g) with 1 and 2 spines, respec tively.

When describing Scolecithrix subdentata, Esterly ( 1905 :167-8, fig. 29c) recorded 5 but wrongly figured 6 setae on Mxl Ri. Apart from this detail, $S$. ovata and $S$. subdentata are morphologically identical, so that the latter should be considered a synonym. Concerning the priority of name, both species descriptions were published in 1905, but only Esterly's publication has the complete date ( 14 October) speci fied. Mr. J M. C. Holmes (National Museum of Ireland, Du blin) kindly informed me that Farran's report was submitted to the Department of Agriculture and Technical Instruction on 8 May 1905, passed by Dublin Castle on 13 May, and was re ceived and stamped, after publication, by the Museum on 5 Au gust. It was therefore published before Esterly's paper, and $S$. ovata Farran must have priority.

The male described by Minoda (1971) is a V copepodite, and is therefore considered of doubtful identification in the synonymy.

Habitat and distribution.- Considered by Wilson (1942, 1950) as a typical Atlantic species, Scolecithricella ovata has however been reported in the Pacific and in antarctic and subantarctic waters (Park, 1980:59) A rare species in the oceanic epipelagial off southern Brazil (present study).

\section{Scolecithricella profunda (Giesbrecht, 1892)

$$
\text { Fig. } 8
$$

Scolecithrix profunda Giesbrecht, 1892:266-86, pl. 13, figs 5, 26.- Giesbrecht and Schmeil, 1898:43.

scolecithricella profunda. - Tanaka, ig62:45-7, fig. 131 ( only).-Vervoort, 1965:80-1.- Park, 1980:36-8, fig. 4 .

scolecithrix abyssalis. - Sars, 1924: pl. 52, figs 7-14.

Scolecithricella abyssalis. - Sars, 1925:189-90.- Rose, 1933: 158, fig. 172.- Rose, 1942:136-9, figs 27-30.-Wilson, $1942: 207$, fig. 132 non fig. 120.- Wilson, 1950:331,pl. 34, fig. 519.- Brodskii, 1950:271-2, fig. 181 (part.).

Material examined.- FINEP/IOUSP collection: 19 , oblique tow from $200 \mathrm{~m}$ to surface in oceanic waters off Rio de Janeiro State at night (Trans. I - Nov./Dec. 75), Lat. $23^{\circ} 46^{\prime} 7 \mathrm{~S}$, Long. $41^{\circ} 4^{\prime} 1 \mathrm{~W}$, SW Atlantic, Brazil.

Type locality.- Mediterranean Sea, Gulf of Naples, Lat. $41^{\circ} \mathrm{N}$.

Remarks.- Total length $1.94 \mathrm{~mm}$. Pr lengthened and dorso-ventrally compressed (Fig. 8a). Mxl Ba2 and Ri (Fig. 8d) with 5 and 8 setae, respectively. Pl Rel (Fig. 8e) without outer terminal spine. P5 (Fig. 8f) symmetrical, inner marginal spi ne with a row of spinules; outer marginal articulated spine short. 


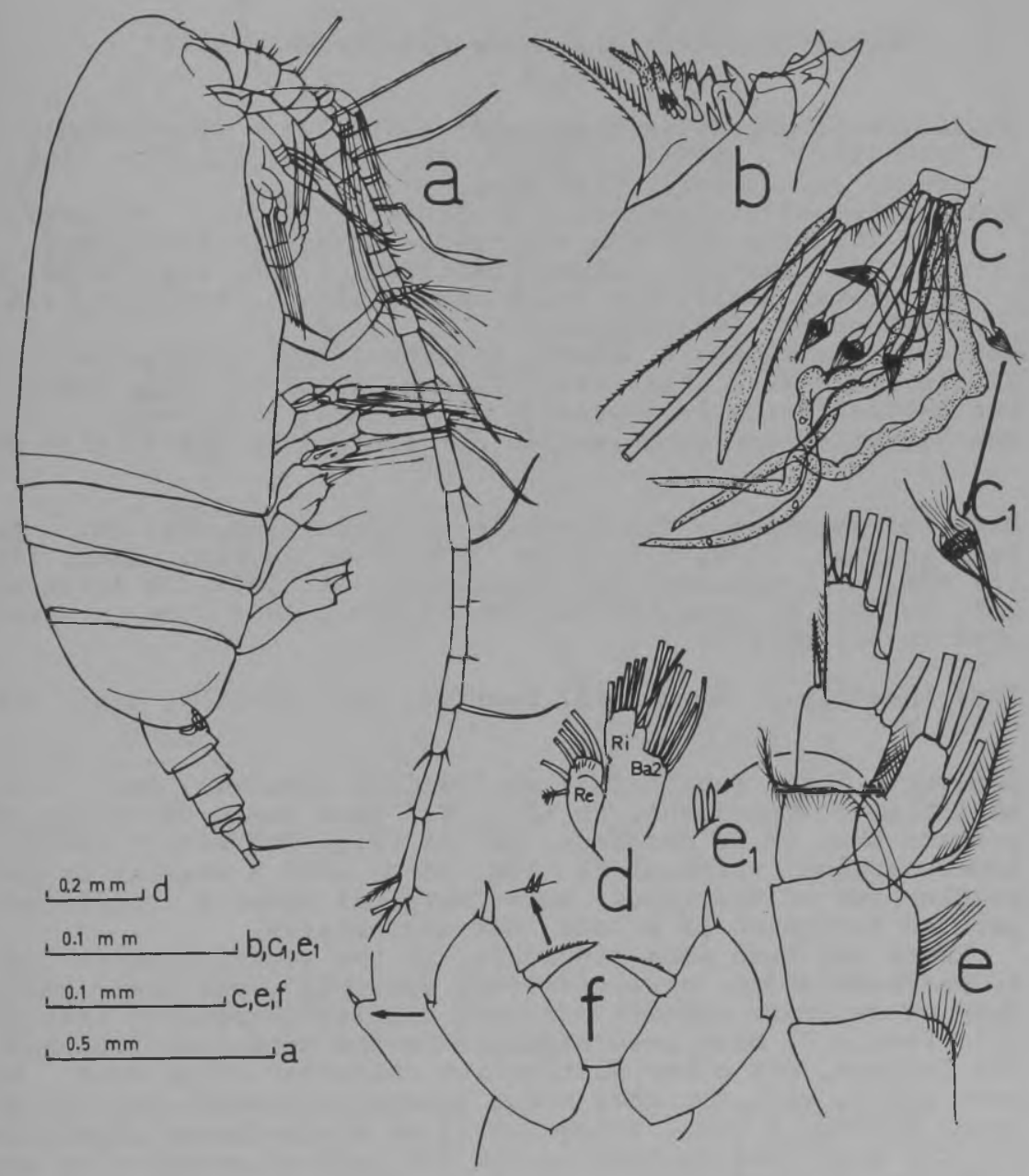

Fig. 8 - Scolecithricella profunda, F. a, Habitus, lateral; $b$, Gnathobasis of Md, masticatory edge; $c$, Max inner lobe 5 and $\mathrm{Ri} ; \mathrm{d}, \mathrm{Mxl} \mathrm{Ba} 2, \mathrm{Ri}$ and $\mathrm{Re} ; \mathrm{e}, \mathrm{Pl}$, posterior; el, Spines on outer lobe of PI Ri, enlarged; f, P5, pair. 
Habitat and distribution.- Mediterranean, Indo-Pacific,tropi cal Atlantic and subantarctic waters (Park, 1980:36-7). A ra re species in the oceanic epipelagial off southern Brazil (present study).

Scolecithricella abyssalis (Giesbrecht, 1888) Fig. 9

Sodlecithrix abys8alis Giesbrecht, 1888:338.- Giesbrecht, 1892:266-86, pl. 13, figs 15, 40, pl. 37, fig. 7.- Gies brecht and Schmeil, 1898:43-4.

Scolecithricella abyssalis.- A. Scott, 1909:89.- Wilson, 1942:207, fig. 120 non fig. 132.- Brodskii, 1950:271-2

fig. 181 (part.).- Grice, 1962:208, pl. 16, figs 16-20. BjB̈rnberg, 1965:225.- Grice and Hulsemann, 1965:221, 224. - Bjornberg, 1973:332-4.

Scolecithrix tumida T Scott, 1894:52-3, pl. 3, figs 33-8. ?Scoleoithricella abyssalis. - Tanaka, 1937:260, fig. 10a-c. non scolecithricella abyssalis o. - Tanaka, 1962:44-5.

non Scolecithricella abyssalis $\sigma^{\circ}$ - Rose, 1942:157-9, figs 49 -52 .

Material examined- (1) MarChile I Expedition, St. 14, SE (2) R/S"M. Lomonosov" XII Expedition, St. 1058 , SW At lantic Lat. $14^{\circ} 00^{\prime} 4 \mathrm{~S}$, Long. $35^{\circ} 01^{\prime} 6 \mathrm{~W}, 27 \mathrm{Nov} ., 1962$, tow from 1040 to $323 \mathrm{~m}: 1$ \%.

Type locality. - Equatorial Pacific, Lat. $11-14^{\circ} \mathrm{N}$, Long. 124 $-132^{\circ} \mathrm{W}$.

Remarks.- Total length $1.87 \mathrm{~mm}$ (Pacific specimen) and 1.92 $\mathrm{mm}$ (Atlantic specimen). Pr (Fig. 9a) less dorso-ventrally com pressed than in $S$. profunda. Mxl Ri (Fig. 9b) with 7 setae Inner marginal spine of P5 (Fig. 9c-d) with a regular or irregular row of denticles; outer marginal spine a chitinized pointed extension of a lobe, not articulated.

There has been some difficulty in the identification of S. profunda and $S$. abyssalis (see synonymy), and their validity as separate species has been doubted (Vervoort, 1965 : $80)$ Female $P 5$ have been regarded as the principal diagnostic feature, but other distinctive characteristics must be considered, viz. the body shape laterally viewed; the Mxl Ri setal number, 8 and 7 respectively in profunda and abyssalis; and the shape and disposition of the seminal receptacles(com pare Fig. 9al with fig. 4c in Park, 1980). Until these featu res are confirmed for both species, it is better to keep them taxonomically apart.

Tanaka (1937, 1962) described the male and female for sco lecithricella profunda and $S$. abyssalis. The female of $S$. profunda is correctly assignable, but that of $S$. abyssalis ought to have more additional characters to be separated from the former. The male attributed to $S$. abyssalis seems to be a misidentification, as may be deduced from his refer- 


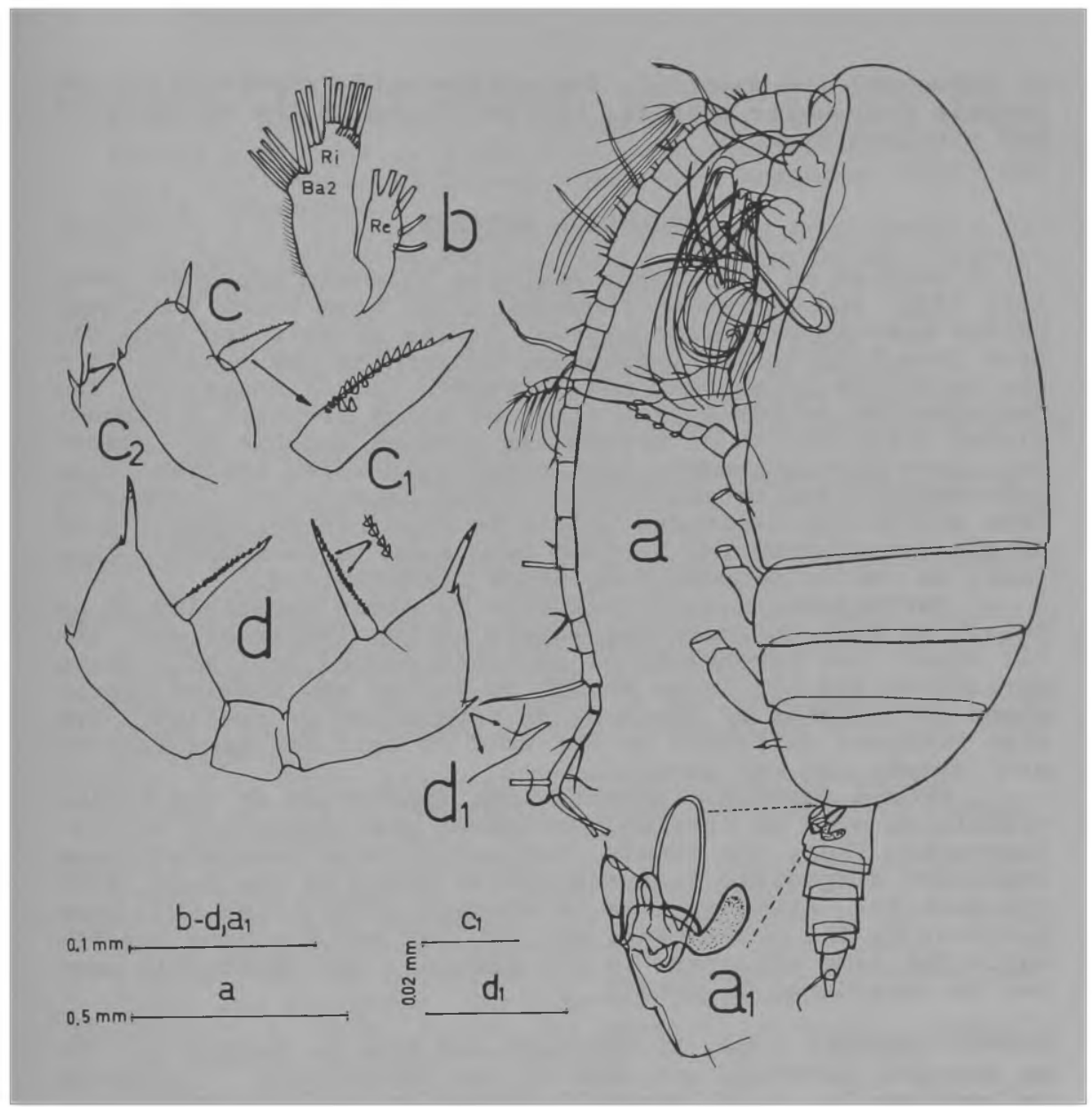

Fig. 9-Scolecithricella abyssalis, +. a, Habitus, lateral; $\mathrm{b}, \mathrm{Mxl} \mathrm{Ba} 2, \mathrm{Ri}$ and Re; c, P5; d, P5, pair. Note.- a,c: Pacific specimen; b, d: Atlantic specimen.

ring of the P5 (1962:45) to that of the male described by him as S. dubia (1937: fig. lle); the other male identified as of $S$. profunda could therefore either be of this species or of $S$. abyssalis.

Rose (1942) attributed his "mâle no 3 " to what he supposed to be $S$. abyssalis, but it is similar to the male which he described as Amallothrix tenuiserrata, considered here as synonymous to $S$. vittata.

Habitat and distribution. - Pacific (Grice, 1962: Grice and Hulsemann, 1965; Bjornberg, 1973) and S Atlantic (T. Scott, 1894; Bjornberg, 1965) Mediterranean records (see s. profun 
da synonymy) are doubtful. Scolecithricella abyssalis is an oceanic deep-water species, not yet found in the epipelagial off southern Brazil.

\section{CONCLUDING REMARKS}

Studies on planktonic deep-sea calanoid copepods (Whee ler, 1970) and ostracods (Deevey, 1983) have shown that most of the species are cosmopolitan, living in cold and cool waters from high to low latitudes. Concerning the epiplankto nic calanoids, Fleminger and Hulsemann (1973) suggested two distribution patterns, the first of which proposes a circumglobal distribution of warm-water species capable of breeding up to mid-latitudes. Similarly, cold-water species from intermediate and/or subtropical water capable of breeding from mid to low latitudes should be also circumglobal. Most of the scolecithricids studied here seem to exemplify this case, as can be deduced from their distribution.

Morphological varieties seem to occur especially in po pulations from near-coastal waters at low latitudes and, until other than morphological analyses can be applied, these variations are not large enough to define new species. Decisions about cases of synonymy or separation of species are also rendered difficult by the want of data for many important areas, not yet sampled.

From a taxonomic aspect, some appendages of the scolecithricids must be carefully observed when described and illustrated. Thus, the female MxI and $P I$ have furnished some important diagnostic features, which could be the case with the male Mxl, although this is strongly simplified in some species. On the other hand, A2, Md, Max and Mxp have practically the same structure in all species, and apparently need not be considered in detail.

ACKNOWLEDGMENTS - Dr. Y, Matsuura and Miss K. Suzuki put at my disposal material and data of the FINEP/IOUSP plankton collection; Dr. G. A. Boxshall looked at Farran's BMNH type material of scolecithrix curta and furnished information and drawings of it; Mr. J M. C. Holmes searched for and provided the approximate date of publication of Farran's 1905 report; Dr. T. K. S. Bjornberg and Dr. E. B. R. Marcus read the manuscript critically. To all I am deeply grateful.

\section{REFERENCES}

BJORNBERG, T.K.S. 1963. On the marine free-living copepods off Brazil. Bolm Inst.Oceanogr., S Paulo 13(1):3-142.

BJORNBERG, T.K.S. 1965. The study of planktonic copepods in the South West Atlantic. Anais Acad.bras.Cienc. 37(2) , suppl.: 219-230.

BJORNBERG, T.K.S. 1973. The planktonic copepods of the Mar Chile I expedition and of the "Eltanin" cruises 3-6 taken in the SE Pacific. Bolm Zool.Biol.Mar. (N.S.) 30:245-394. 
BJÓRNBERG, T.K.S. 1981. Copepoda. pp. 587-679. In: D. Bol tovskoy, ed., Atlas del zooplancton del At lantico sudocci dental y métodos de trabajo con zooplancton marino, $93 \overline{6}$ pp., Inst. Nacional Invest. Desarollo Pesquero, Mar del Plata, Argentina.

BRADFORD, J.M. 1973. Revision of family and some generic definitions in the Phaennidae and Scolecithricidae (Copepoda: Calanoida). N.2.Jl Mar.Freshwat.Res. 7(1 \& 2): 133-152. BRODSKII, K.A. 1950. Calanoida of the Far Eastern Seas and Polar Basin of the U.S.S.R. Keys to the Fauna of the U.S.S.R., The Zoological Institute of the Academy of Sciences of the U.S.S.R. 35:1-442 (English transl. from Russian by A. Mercado, Israel Program for Scientific Trans lations, Jerusalem, 1967).

DEEVEY, G.B. 1983. Planktonic ostracods (Myodocopa, Halocy prididae) from six Eltanin cruises in South Pacific and Antarctic waters. J.Crust.Biol. 3(3):409-416.

ESTERLY, C.0. 1905. The pelagic Copepoda of the San Diego re gion. Univ. Calif.Puble Zool. 2(4):113-233.

FARRAN, G.P. 1905. Report on the Copepoda of the Atlantic slope off Counties Mayo and Galway. Scient. Invest. Fish. Brch Ire 1902-03, No II, App. II:23-52

FARRAN, G.P. 1908. Second report on the Copepoda of the Irish Atlantic slope. Scient.Invest.Fish. Brch Ire 1906, No II:19-120.

FARRAN, G.P. 1926. Biscayan plankton collected during a cruise of H.M.S. "Research", 1900. Part XIV The Copepo da. J.Linn.Soc., 200l. 36:219-310.

FARRAN, G.P 1929. Crustacea, Part X - Copepoda. Br.Antarct. Terra Nova Exped. 1910 (Zool.) 8(3):203-306.

FLEMINGER, A. \& K. HULSEMANN, 1973. Relationship of Indian Ocean epiplanktonic calanoids to the world oceans. pp. 339-347 In: B. Zeitzschel, ed., Ecological studies. AnaZysis and Synthesis, Springer-Verlag, Berlin.

GIESBRECHT, W. 1888. Elenco dei copepodi pelagici raccolti dal tenente di vascello Gaetano Chierchia durante il viaggio della R. Corvetta "Vettor Pisani" negli anni 1882 -1885 e dal tenente di vascello Francesco Orsini nel Mar Rosso, nel 1884. Atti Accad.naz. Lincei Rc.(4) 4:284 $287,330-338$.

GIESBRECHT, W. 1892. Systematik und Faunistik der pela gischen Copepoden des Golfes von Neapel und der angrenzen den Meeres-Abschnitte. Fauna Flora Golf. Neapel 19:1-831, 54 pls.

GIESBRECHT, W. \& 0. SCHMEIL. 1898. Copepoda. I. Gymnoplea. Tierreich $6: 1-169$.

GRICE, G.D. 1961 (1962) Calanoid copepods from equatorial waters of the Pacific Ocean. Fishery Bull. Fish Wildi.Serv. U.S. $61(186): 171-246$.

GRICE, G.D. \& K. HULSEMANN. 1965. Abundance, vertical distri bution and taxonomy of calanoid copepods at selected sta= tions in the northeast Atlantic. J.20ol., London $146(2)$ : 213-262.

HURE, J \& B. SCOTTO DI CARLO. 1968. Two new species of Scaphocalanus (Copepoda: Calanoida) from the Mediterranean 
Sea. Pubbl.Staz.zool. Napoli 36:152-166.

MINODA, T. 1971. Pelagic Copepoda in the Bering Sea and the northwestern North Pacific with special reference to their vertical distribution. Mem.Fac.Fish.Hokkaido Univ $18(1-2): 1-74$.

OWRE, H.B. \& M. FOYO. 1967 Crustacea. Part I: Copepoda. Copepods of the Florida Current. Fauna Caribaea 1(1):1-137.

PARK, T.S. 1968. Calanoid copepods from the central North Pa cific Ocean. Fishery Bull. Fish WildL.Serv. U.S. $66(3): 527$ -572 .

PARK, T.S. 1970. Calanoid copepods from the Caribbean Sea and Gulf of Mexico 2. New species and new records from plankton samples. Bull.mar.Sci. 20(2):472-546.

PARK, T.S. 1980. Calanoid copepods of the genus Scolecithricezla from antarctic and subantarctic waters. Biology of the Antarctic seas IX. Antarctic Res.Ser. 31(2):25-79.

PARK, T.S. 1982. Calanoid copepods of the genus scaphocalanus from antarctic and subantarctic waters. Biology of the Antarctic seas XI. Antarctic Res.Ser. 34:75-127.

ROSE, M. 1933. Copépodes pélagiques. Faune Fr. 26:1-374.

ROSE, M. 1942. Les Scolecithricidae (Copépodes pélagiques) de la Baie d'Alger. Annls Inst.océanogr., Monaco, (N.S.), 21 (3) : 113-170.

SARS, G.0. 1924, 1925. Copépodes particulièrement bathypélagiques provenant des campagnes scientifiques du Prince Al bert 1 ef de Monaco. Résult. Camp.scient. Prince Albert $\bar{I}$ 69:1-408 (1925), 127 pls (1924).

SCOTT, A. 1909. The Copepoda of the Siboga Expedition, Part I - Free-swimming, littoral and semi-parasitic Copepoda Siboga Exped. 29a:1-323, 69 pls.

SCOTT, T 1894. Report on Entomostraca from the Gulf of Gui nea, collected by John Rattray, B. Sc. Trans.Linn.Soc. Lond., 2nd ser., Zoology 6(1):1-161.

TANAKA, 0. 1937. Copepods from the deep water of Suruga Bay. JaP.J.ZOol. $7(2): 251-271$.

TANAKA, 0. 1953. The pelagic copepods of the Izu region.Rec. oceanogr. Wks Japan (N.S.), 1(1):126-137.

TANAKA, 0. 1961. The pelagic copepods of the Izu region,middle Japan, systematic account VII - Family Scolecithricidae (part 1) Publs Seto mar.biol.Lab. 9(1):139-190.

TANAKA, 0. 1962. The pelagic copepods of the Izu region, midle Japan, systematic account VIII - Family Scolecithricidae (part 2) Publs seto mar, biol.Lab. 10(1):35-90.

VAUPEL KLEIN, J.C. VON. 1982. A taxonomic review of the ge nus Euchirelia Giesbrecht, 1888 (Copepoda, Calanoida), IGeneral part. 200l. Verh. 197:1-48.

VERVOORT, W. 1951. Plankton copepods from the Atlantic sec tor of the Antarctic. Verh.K.ned.Akad. Wet., Afd.Natuurkun de (2) $47(4): 1-156$.

VERVOORT, W. 1957. Copepods from antarctic and subantarctic plankton samples. Rep.B.A.N.Z.antarct.Res.Exped., ser.B (Zoology and Botany) 3:1-160.

VERVOORT, W. 1965. Pelagic Copepoda, Part II - Copepoda Cala noida of the families Phaennidae up to and including Acar tiidae, containing the description of a new species of $A \underline{e}$ tideidae. At lantide Rep. 8:9-216. 
WHEELER, E.H., JR. 1970. Atlantic deep-sea calanoid Copepoda. Smithson. Contr. 20ol. 55:1-31.

WILSON, C.B. 1942. The copepods of the plankton gathered during the last cruise of the Carnegie. Scient.Results Crui se VII Carnegie, Biology 1:1-237.

WILSON, C.B. 1950 Copepods gathered by the United States fisheries steamer "Albatross" from 1887 to 1909 , chiefly in the Pacific Ocean. Bul2.U.S.natn.Mus. 14(4):141-441. WITH, C. 1915. Copepoda I - Calanoida Amphascandria. Dan. Ingolf-Exped. $3(4): 1-260$. 
